\title{
Analisa Pengaruh Ukuran Partikel terhadap Patahan Gritcone pada Vertical Roller Mill Dengan Simulasi Explicit Dynamic (Ls-Dyna)
}

\author{
Muhammad Arsyad Putra P, Mas Irfan P Hiadyat dan Rochman Rochiem \\ Jurusan Teknik Material dan Metalurgi, Fakultas Teknologi Industri, Institut Teknologi Sepuluh Nopember \\ (ITS) \\ Jl. Arief Rahman Hakim, Surabaya 60111 Indonesia
}

\begin{abstract}
Absrak - Polysius vertical roller mill (Polysius VRM) adalah alat penggiling yang digunakan di PT Holcim Indonesia Tuban Plant untuk menggiling batu bara yang digunakan sebagai bahan bakar kiln pada tahap produksi semen. Pada pengoperasiannya sering terjadi kegegalan pada bagian Gritcone. Komponen ini mengarahkan batu bara yang ukurannya tidak sesuai lolos penyaringan oleh separator kembali ke grinding table untuk digiling kembali. Dengan menggunakan simulasi Explicit Dynamuc Ls- Dyna melalui software ANSYS dapat diketahui ketebalan Gritcone setelah satu siklus. Pada simulasi kali ini diperoleh ketebalan gritcone setelah satu kali siklus dengan hasil sebagai Ketebalan gritcone minimum pada Persebaran 75 \% dan $100 \%$ adalah $0.00998403 \mathrm{~m}$ dan $0.00999324 \mathrm{~m}$. Ketebalan gritcone maksimum pada Persebaran $75 \%$ dan $100 \%$ adalah $0.00998715 \mathrm{~m}$ dan $0.0099775 \mathrm{~m}$.
\end{abstract}

Kata kunci : Desain, Grit Cone, Batu Bara, Polysius Vertical Roller Mill, Holcim, Expilicit Dynamic Ls Dyna, ANSYS

\section{PENDAHULUAN}

$\mathrm{V}$ ertical Roller Mill memiliki banyak bentuk yang berbeda, tetapi bekerja pada prinsip sama. Semua jenis Vertical Roller Mill memiliki bentuk yang sama yaitu dengan adanya roller dan roller yang bergerak sepanjang jalur dari lingkaran oleh rol penggilingan dalam bentuk tekanan vertikal sehingga menghasilkan kompresi yang bertujuan untuk menghancurkan material benda tersebut.Pada Holcim Indonesia alat yang digunakan untuk menghasilkan batu bara yang sesuai maka digunakan Vertical Roller Mill.

PT Holcim Indonesia yang berada di tuban memiliki 2 buah Vertical Roller Mill yang terus beroperasi . Pada pengoprasian Vertical Roller mill sering terjadi kerusakan maka dari itu diperlukan permodelan untuk menganalisa kerusakan.pemodelan secara numerik ini banyak dilakukan karena dapat menjadi kerusakan pada bagian gritcone.dan dari pihak holcimpun sudah berusaha untuk melakukan maintanance pada Gritcone, namun hasil yang diperolah belum memuaskan. Maka dari itu diperlukan evaluasi pada ukuran partikel coal mill.

Agar mendapatkan hasil penelitian yang baik maka digunakan pemodelan dengan menggunakan konsep Explicit Dynamic LS-Dyna yang bertujuan untuk mengamati aliran fluida Batu Bara pada Vertical Roller Mill. Metode bahan evaluasi yang efektif dan efisien dalam penelitian.

Salah satu software yang menggunakan prinsip Explicit Dynamic LS-Dyna adalah ANSYS. Penggunaan simulasi dengan software ANSYS dilakukan karena lebih efisien waktu dan harga .Dalam penelitian ini akan di lakukan analisis aliran fluida pada Vertical Roller Mill dengan Pengaruh pada ukuran partikel Coal dengan menggunakan software ANSYS/Mechanical APDL Ver 17.1 untuk memperoleh desain yang paling optimal.

\section{METODE PENELITIAN}

\section{A. Spesifikasi Material}

Material Gritcone yang digunakan dalam penilitian kali ini adalah berjenis wear plate.Dalam penilitian kali ini untuk sifat mekanik dari Gritcone disajikan pada Tabel dibawah ini:

Tabel 1

Sifat Mekanik Gritcone

\begin{tabular}{ll}
\hline Sifat Mekanik & Nilai \\
\hline Density & 7860 \\
Kekuatan Tarik & $2000 \mathrm{Mpa}$ \\
Poisson's ratio & 0.3 \\
\hline
\end{tabular}

Batu bara yang digunakan dalam penilitian adalah jenis Bitouminus. Untuk sifat mekanik ${ }^{[1]}$ dari batu bara yang digunakan disajikan pada tabel dibawah ini:

Tabel 2

Sifat Mekanik dari Batu bara

\begin{tabular}{cc}
\hline Sifat mekanik & Bituminous \\
\hline Kekuatan tarik (Mpa) & 1641 \\
Poisson's ratio & 0.35 \\
Kekerasan (Vickers) & $10-70$
\end{tabular}

Tabel 1 dan tabel 2 menunjukkan sifat mekanik gritcone. Untuk dimensi dari Gritcone pada material ini disajikan pada gambar dibawah ini: 


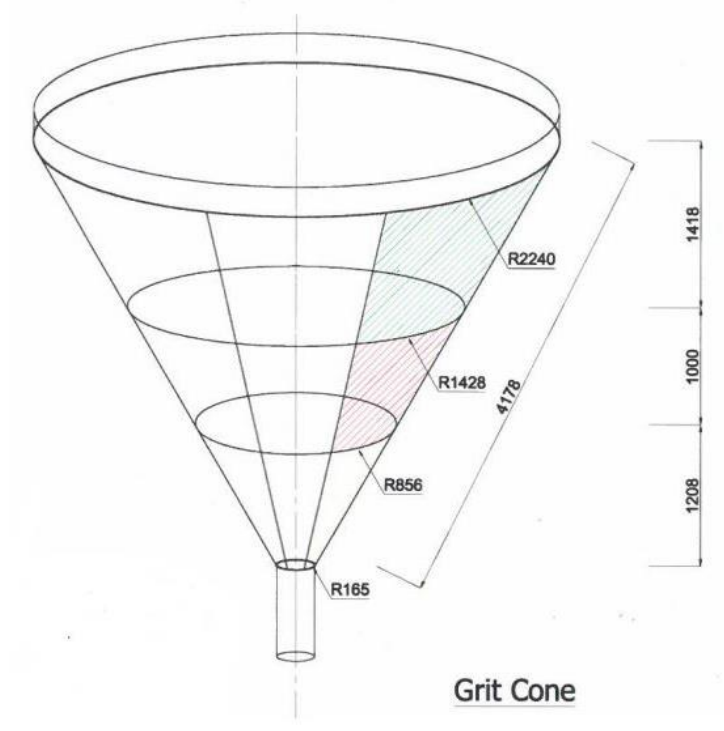

Gambar 1 Desain Gritcone

\section{B. Pemodelan}

Pemodelan pada penilitian ini menggunakan PC Inter Pentium (R) 2030 Dual CPU 3.00 Ghz, RAM 8 Giga dengan perangkat lunak Ansys Mechanical APDL Release 17.1 sementara elemen yang digunakan adalah Shel 163 untuk Gritcone dan Mass 166 untuk material batu bara.

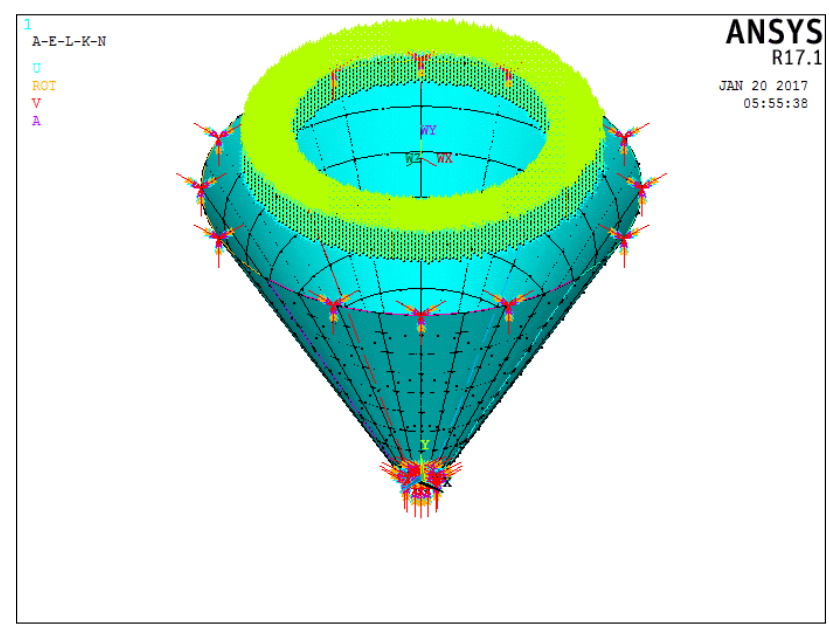

Gambar 2 Hasil pemodelan

Gambar 2 menunjukkan pemodelan pada material. Pemberian beban berupa displacement (panah warna merah) tepat ditengah pada material komposit, sementara di bagian ujung diberikan constraint, initial crack diletakan ditengah dan ditunjukkan dengan warna putih.

\section{Parameter Penilitian}

Untuk mengatahui seberapa besar pengaruh ukuran partikel terhadap patahan Gritcone ini, maka diberikan parameter penilitian yang dijelaskan didalam tabel yang ada dibawah ini
Parameter Penilitian

Dalam Penilitian kali ini dilakukan dalam 2 persebaran

\begin{tabular}{crrr}
\hline Case & Ukuran Partikel & $\begin{array}{c}\text { Persebaran } \\
\text { Partikel }\end{array}$ & $\begin{array}{c}\text { Jumlah } \\
\text { Partikel }\end{array}$ \\
\hline 1 & $100 \mu \mathrm{m}$ & $75 \%$ & 1980 \\
2 & $120 \mu \mathrm{m}$ & $75 \%$ & 1980 \\
3 & $150 \mu \mathrm{m}$ & $75 \%$ & 1980 \\
4 & $100 \mu \mathrm{m}$ & $100 \%$ & 1980 \\
5 & $120 \mu \mathrm{m}$ & $100 \%$ & 1980 \\
6 & $150 \mu \mathrm{m}$ & $100 \%$ & 1980 \\
\hline
\end{tabular}

\section{HASIL DAN PEMBAHASAN}

Dalam Penilitian kali ini . Dengan Menggunakan Variabel bebas ukuran Partikel yaitu sebesar $100 \mu \mathrm{m}$ dan $120 \mu \mathrm{m}$. Dan Dikarenakan Elemen Type yang digunakan Mass 166 maka ukuran dari partike tersebut perlu dikonversi ke Massa dengan cara Mengalikan

Volume Partikel tersebut dengan Massa Jenis Batu bara yaitu $833 \mathrm{Kg} / \mathrm{m}^{3}$. Dan Untuk Bentuk dari Partikel tersebut dianggap Berbentuk Bola. Sehingga diperoeh Massa Batu Bara pada beberbagai Ukuran Partikel.

\section{A. Persebaran Partikel $75 \%$}

Pada Eksperimen kali ini, Melakukan Simulasi pada 2 kondisi yaitu pada kondisi persebaran Material $75 \%$ dan $100 \%$. Untuk hasil-hasil yang ada dibawah disolve dengan menggunakan Software Ansys 17.1 dan untuk hasilnya dilihat dengan menggunakan Software LS Prepost .

- Ukuran partikel $100 \mu \mathrm{m}$
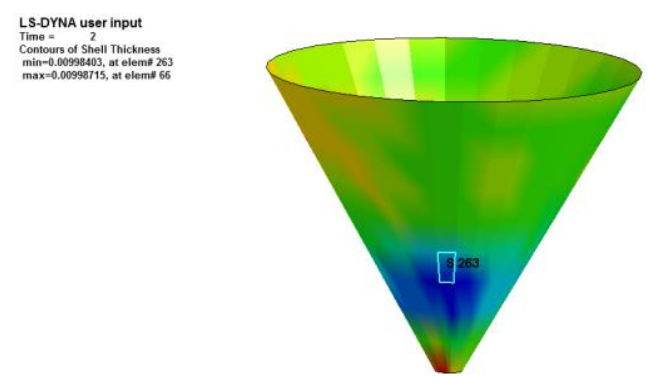

Gambar 3 Ketebalan Gritcpone pada persebaran Material 75\%, pada ukuran partikel $100 \mu \mathrm{m}$

Pada Gambar 4.1 memunjukan tebal gritcone setelah satu siklus dan dari grafik tersebut dapat dilihat persebaran ketebalan gritcone tersebut.dan ketebalan minimum adalah $0.00998403 \mathrm{~m}$ dan ketebalan maksimum dari partikel tersebut $0.00998715 \mathrm{~m}$. dari simulasi yang dilakukan juga dapat melihat pengaruh waktu terhadap ketebalan dari 2 lokasi tersebut 


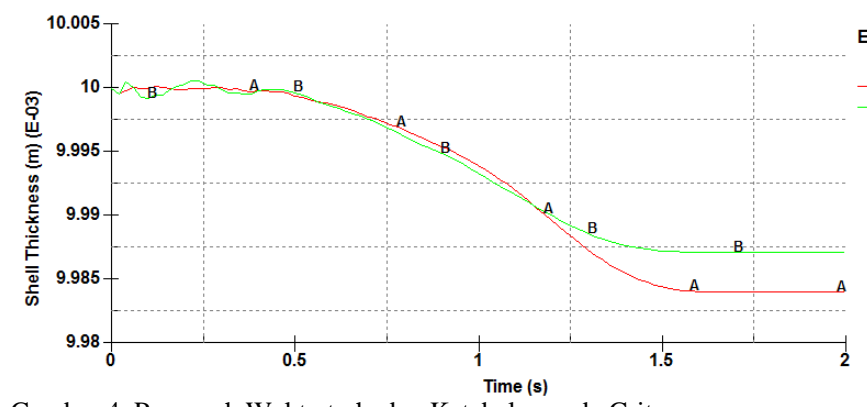

Gambar 4 Pengaruh Waktu terhadap Ketebalan pada Gritcone

Pada Gambar 4 dapat terlihat bahwa Penipisan Gritcone dimulai pada saat waktu $0.5 \mathrm{~s}$.setelah waktu tersebut terjadi pengurangan ketebalan yang cukup signifikan pada elemen ke 263 Dan letak Elemen tersebut berada pada ketinggian $0.8-1$ $\mathrm{m}$ dari dasar Gritcone.

Adapun dari simulasi kali ini diperoleh tegangaan Von Misses sebagai membantu dalam memperkuat analisa mengenai pengaruh ukuran partikel ini.
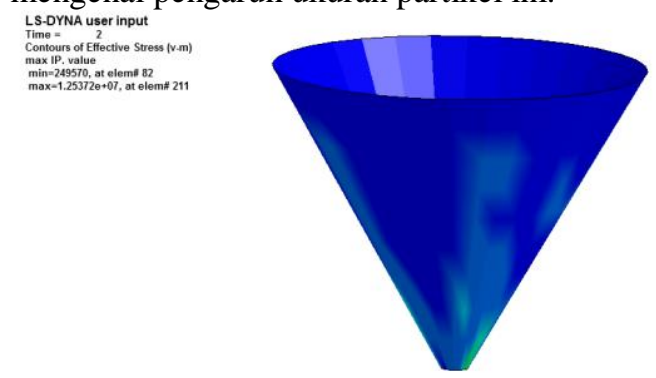

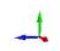

Gambar 5 Von Misses Pada Gritcone untuk spesimen 1

Pada Gambar 5 menunjukan Distrbusi tegangan Von Misses dari Grtitcpne .Dapat ditemukan intesitas stress yang lebih tinggi ditemukan di bagian bawah dari gritcone .dan dalam hasil tersebut terlihat stress yang paling tinggi terjadi di Elemen ke 211 berada di ketinggian 3 - $3.2 \mathrm{~m}$ dari dasar gritcone dengan nilai tegangan sebesar $12537200 \mathrm{~Pa}$.

- Ukuran partikel $120 \mu \mathrm{m}$
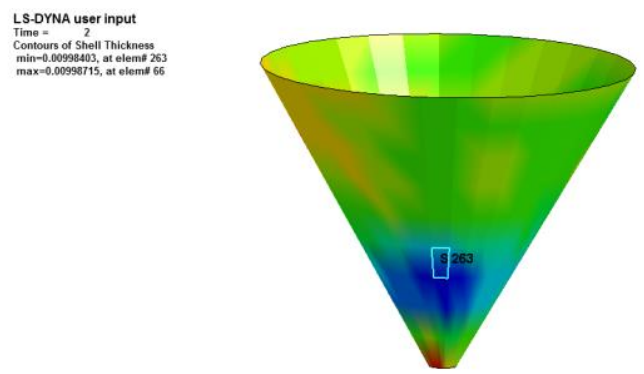

$+1$

Gambar 6 Ketebalan Gritcpone pada persebaran Material 75\%, pada ukuran partikel $120 \mu \mathrm{m}$

Pada Gambar 6 memunjukan tebal gritcone setelah satu siklus dan dari grafik tersebut dapat dilihat persebaran ketebalan gritcone tersebut.dan ketebalan minimum adalah $0.00998403 \mathrm{~m}$ dan ketebalan maksimum dari partikel tersebut $0.00998715 \mathrm{~m}$. dari simulasi yang dilakukan juga dapat melihat pengaruh waktu terhadap ketebalan dari 2 lokasi tersebut.

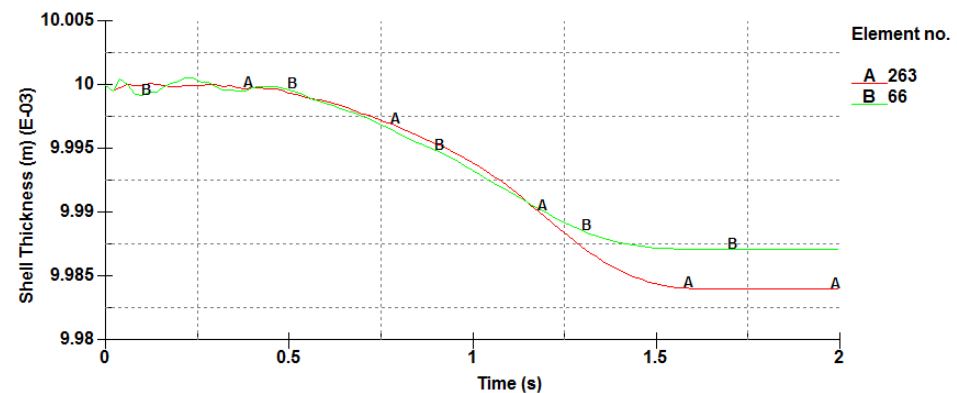

Gambar 7 Pengaruh Waktu terhadap Ketebalan pada Gritcone

Pada Gambar 7 dapat terlihat bahwa Penipisan Gritcone dimulai pada saat waktu $0.5 \mathrm{~s}$.setelah waktu tersebut terjadi pengurangan ketebalan yang cukup signifikan pada elemen ke 277. Dan letak Elemen tersebut berada pada ketinggian 0.8 - 1 $\mathrm{m}$ dari dasar Gritcone.

Adapun dari simulasi kali ini diperoleh tegangaan Von Efec Misses sebagai membantu dalam memperkuat analisa mengenai pengaruh ukuran partikel ini.
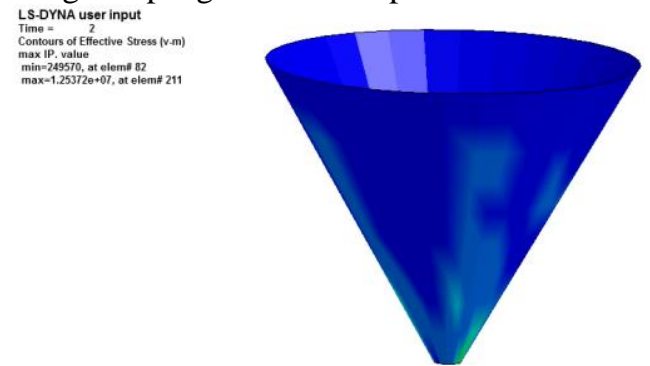

$+1$

Gambar 8 Von Misses Pada Gritcone untuk spesimen 2

Pada Gambar 8 menunjukan Distrbusi tegangan Von Misses dari Grtitcpne .Dapat ditemukan intesitas stress yang lebih tinggi ditemukan di bagian bawah dari gritcone .dan dalam hasil tersebut terlihat stress yang paling tinggi terjadi di Elemen ke 211 berada di ketinggian 3 - $3.2 \mathrm{~m}$ dari dasar gritcone dengan nilai tegangan sebesar $12537200 \mathrm{~Pa}$.

- ukuran artikel $150 \mu \mathrm{m}$
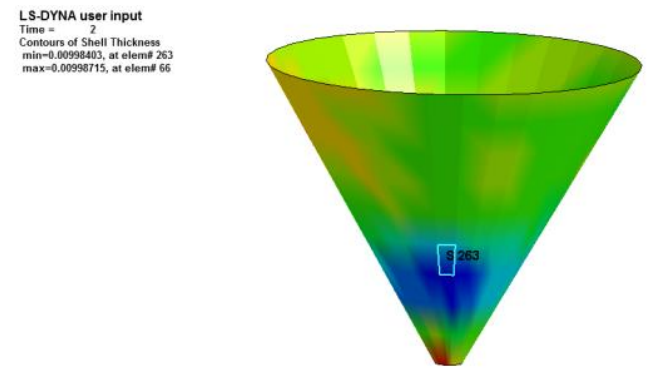

$+1$

Gambar 9 Ketebalan Gritcpone pada persebaran Material 75\%, pada ukuran partikel $150 \mu \mathrm{m}$

Pada Gambar 9 memunjukan tebal gritcone setelah satu siklus dan dari grafik tersebut dapat dilihat persebaran ketebalan gritcone tersebut.dan ketebalan minimum adalah $0.00998403 \mathrm{~m}$ dan ketebalan maksimum dari partikel tersebut $0.00998715 \mathrm{~m}$. dari simulasi yang dilakukan juga dapat 
melihat pengaruh waktu terhadap ketebalan dari 2 lokasi tersebut.

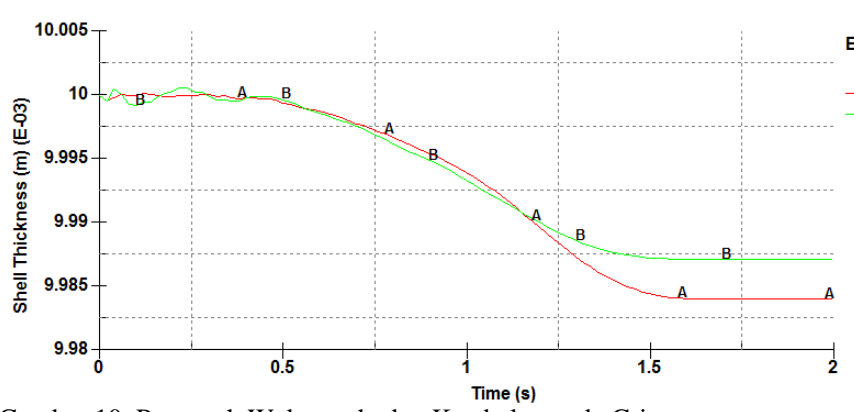

Eleme A 26

Gambar 10 Pengaruh Waktu terhadap Ketebalan pada Gritcone

Pada Gambar 10 dapat terlihat bahwa Penipisan Gritcone dimulai pada saat waktu $0.5 \mathrm{~s}$.setelah waktu tersebut terjadi pengurangan ketebalan yang cukup signifikan pada elemen ke 263. Dan letak Elemen tersebut berada pada ketinggian $0.8-1$ m dari dasar Gritcone.

Adapun dari simulasi kali ini diperoleh tegangaan Von Misses sebagai membantu dalam memperkuat analisa mengenai pengaruh ukuran partikel ini.
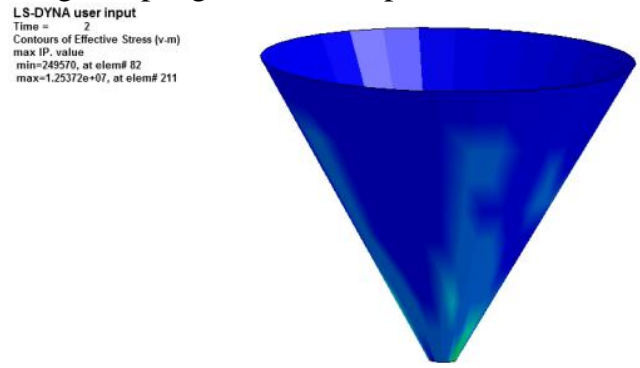

$-1$

Gambar 11 Von Misses Pada Gritcone untuk spesimen 3

Pada Gambar 11 menunjukan Distrbusi tegangan Von Misses dari Grtitcpne .Dapat ditemukan intesitas stress yang lebih tinggi ditemukan di bagian bawah dari gritcone .dan dalam hasil tersebut terlihat stress yang paling tinggi terjadi di Elemen ke 211 berada di ketinggian 3 - $3.2 \mathrm{~m}$ dari dasar gritcone dengan nilai tegangan sebesar $12537200 \mathrm{~Pa}$.

\section{PADA PERSEBARAN PARTIKEL $100 \%$}

- Ukuran partikel $100 \mu \mathrm{m}$
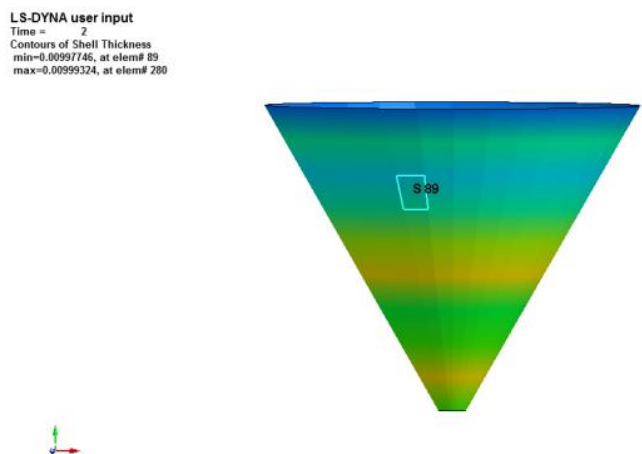

Gambar 12 Ketebalan Gritcpone pada persebaran Material 100\%, pada ukuran partikel $100 \mu \mathrm{m}$
Pada Gambar 12 memunjukan tebal gritcone setelah satu siklus dan dari grafik tersebut dapat dilihat persebaran ketebalan gritcone tersebut.dan ketebalan minimum adalah $0.00997746 \mathrm{~m}$ dan ketebalan maksimum dari partikel tersebut $0.00999324 \mathrm{~m}$. dari simulasi yang dilakukan juga dapat melihat pengaruh waktu terhadap ketebalan dari 2 lokasi tersebut

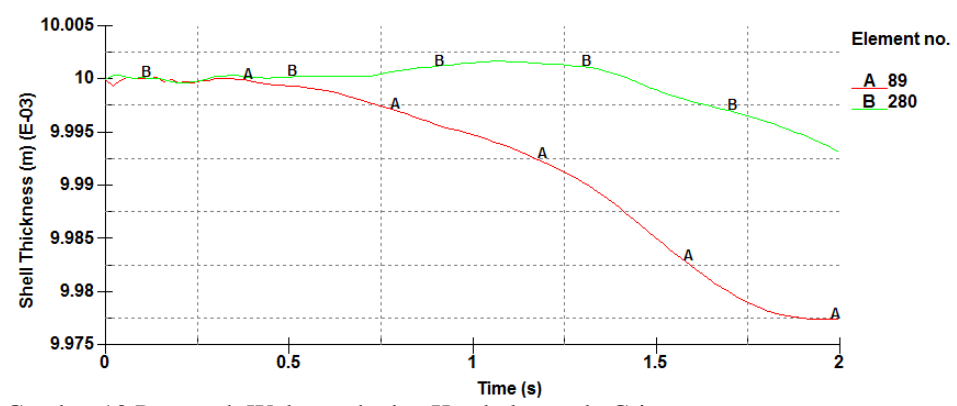

Gambar 13 Pengaruh Waktu terhadap Ketebalan pada Gritcone

Pada Gambar 13 dapat terlihat bahwa Penipisan Gritcone dimulai pada saat waktu $0.4 \mathrm{~s}$.setelah waktu tersebut terjadi pengurangan ketebalan yang cukup signifikan pada elemen ke Eteca 280 .

Adapun dari simulasi kali ini diperoleh tegangaan Von Misses sebagai membantu dalam memperkuat analisa mengenai pengaruh ukuran partikel ini.
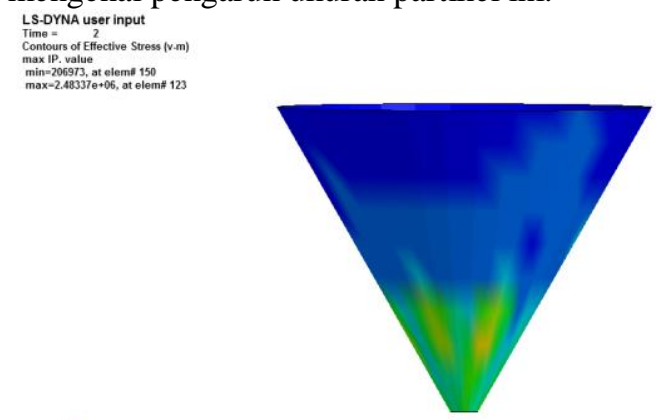

Gambar 14 Von Misses Pada Gritcone untuk spesimen 4

Pada Gambar 14 menunjukan Distrbusi tegangan Von Misses dari Grtitcpne .Dapat ditemukan intesitas stress yang lebih tinggi ditemukan di bagian bawah dari gritcone .dan dalam hasil tersebut terlihat stress yang paling tinggi terjadi di Elemen ke 123 berada di ketinggian 0.8 - $1 \mathrm{~m}$ dari dasar gritcone dengan nilai tegangan sebesar $2483370 \mathrm{~Pa}$.

- Ukuran partikel $120 \mu \mathrm{m}$
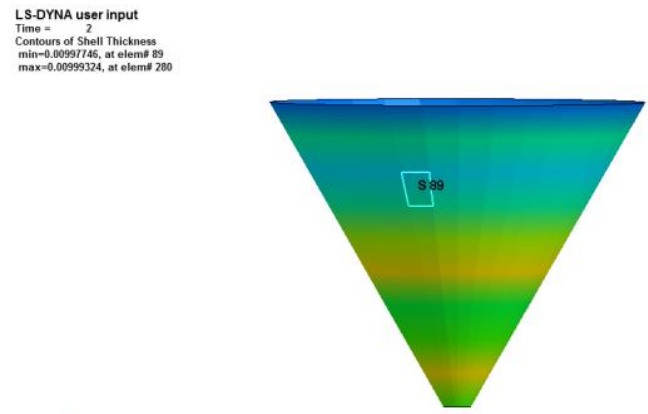

Gambar 15 Ketebalan Gritcpone pada persebaran Material 100\%, pada ukuran partikel $120 \mu \mathrm{m}$ 
Pada Gambar 15 memunjukan tebal gritcone setelah satu siklus dan dari grafik tersebut dapat dilihat persebaran ketebalan gritcone tersebut.dan ketebalan minimum adalah $0.00997746 \mathrm{~m}$ dan ketebalan maksimum dari partikel tersebut $0.00999324 \mathrm{~m}$. dari simulasi yang dilakukan juga dapat melihat pengaruh waktu terhadap ketebalan dari 2 lokasi tersebut

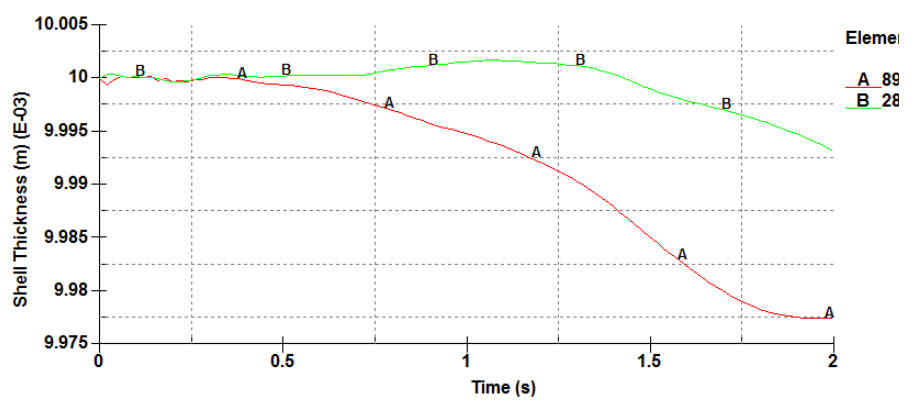

Gambar 16 Pengaruh Waktu terhadap Ketebalan pada Gritcone

Pada Gambar 16 dapat terlihat bahwa Penipisan Gritcone dimulai pada saat waktu $0.4 \mathrm{~s}$.setelah waktu tersebut terjadi pengurangan ketebalan yang cukup signifikan pada elemen ke 280.

Adapun dari simulasi kali ini diperoleh tegangaan Von Misses sebagai membantu dalam memperkuat analisa mengenai pengaruh ukuran partikel ini.
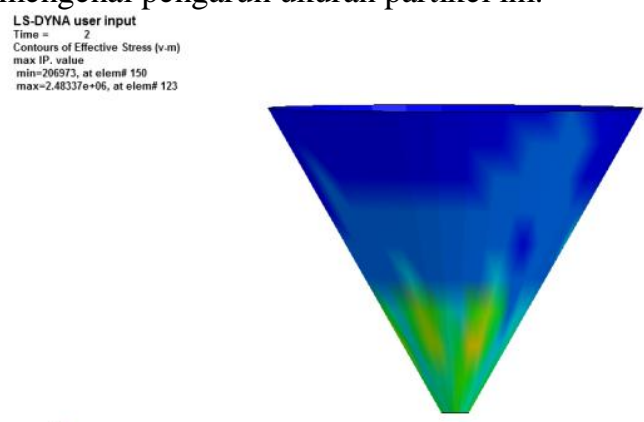

Gambar 17 Von Misses Pada Gritcone untuk spesimen 5

Pada Gambar 17 menunjukan Distrbusi tegangan Von Misses dari Grtitcpne .Dapat ditemukan intesitas stress yang lebih tinggi ditemukan di bagian bawah dari gritcone .dan dalam hasil tersebut terlihat stress yang paling tinggi terjadi di Elemen ke 123 berada di ketinggian $0.8-1 \mathrm{~m}$ dari dasar gritcone dengan nilai tegangan sebesar $2483370 \mathrm{~Pa}$.

- Ukuran partikel $150 \mu \mathrm{m}$

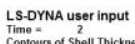

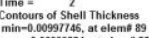

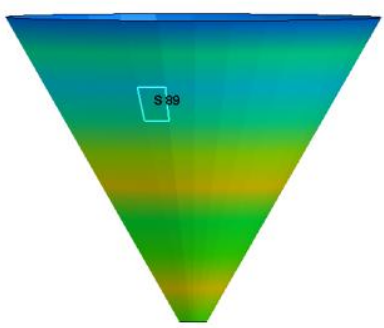

Gambar 18 Ketebalan Gritcpone pada persebaran Material 100\%, pada ukuran partikel $150 \mu \mathrm{m}$
Pada Gambar 18 memunjukan tebal gritcone setelah satu siklus dan dari grafik tersebut dapat dilihat persebaran ketebalan gritcone tersebut.dan ketebalan minimum adalah $0.00997746 \mathrm{~m}$ dan ketebalan maksimum dari partikel tersebut $0.00999324 \mathrm{~m}$. dari simulasi yang dilakukan juga dapat melihat pengaruh waktu terhadap ketebalan dari 2 lokasi tersebut.

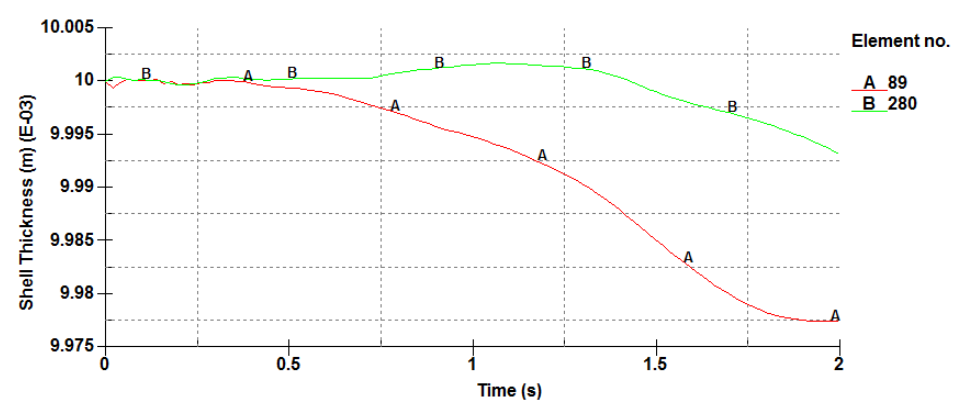

Gambar 19 Pengaruh Waktu terhadap Ketebalan pada Gritcone

Pada Gambar 19 dapat terlihat bahwa Penipisan Gritcone dimulai pada saat waktu $0.4 \mathrm{~s}$.setelah waktu tersebut terjadi pengurangan ketebalan yang cukup signifikan pada elemen ke 280.

Adapun dari simulasi kali ini diperoleh tegangaan Von Misses sebagai membantu dalam memperkuat analisa mengenai pengaruh ukuran partikel ini.
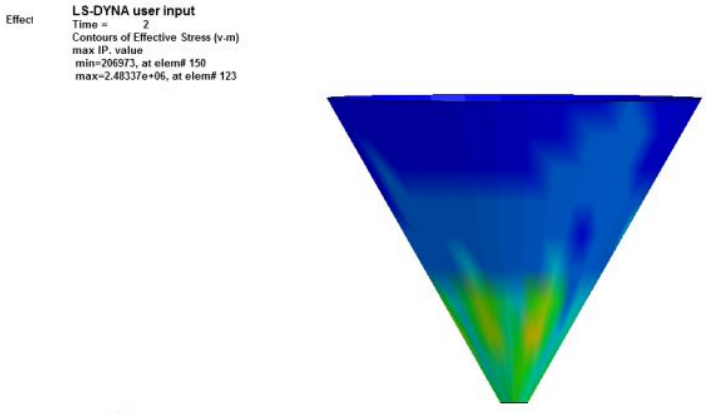

Gambar 20 Von Misses Pada Gritcone untuk spesimen 6

Pada Gambar 20 menunjukan Distrbusi tegangan Von Misses dari Grtitcpne .Dapat ditemukan intesitas stress yang lebih tinggi ditemukan di bagian bawah dari gritcone dan dalam hasil tersebut terlihat stress yang paling tinggi terjadi di Elemen ke 123 berada di ketinggian $0.8-1 \mathrm{~m}$ dari dasar gritcone dengan nilai tegangan sebesar $2483370 \mathrm{~Pa}$.

\section{PEMBAHASAN}

Dari hasil simulasi yang sudah ada kita miliki kita menganalisa pengaruh ukuran partikel terhadap 2 Kondisi Pada Kondisi persebaran partikel $75 \%$ kita dapat menyimpulkan data yang kita miliki 
Tabel 4

Simulasi Pada Kondisi Persebaran 75\%

\begin{tabular}{ccc}
\hline \multirow{2}{*}{ Ukuran } & \multicolumn{2}{c}{ Ketebalan $(\mathrm{m})$} \\
\cline { 2 - 3 } Partikel & Maksimum & Minimum \\
\cline { 2 - 3 } $100 \mu \mathrm{m}$ & $1,29 \mathrm{E}-05$ & $1,60 \mathrm{E}-05$ \\
$120 \mu \mathrm{m}$ & $1,29 \mathrm{E}-05$ & $1,60 \mathrm{E}-05$ \\
$150 \mu \mathrm{m}$ & $1,29 \mathrm{E}-05$ & $1,60 \mathrm{E}-05$ \\
\hline
\end{tabular}

Dari Tabel 4 kita dapat menghitung pengurangan ketebalan gritcone dan dirangkum dalam Gambar 21

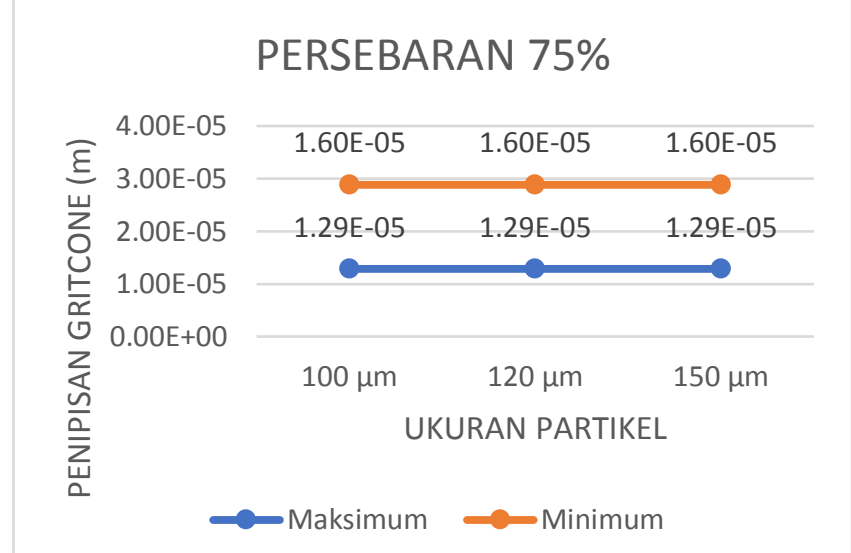

Gambar 21 Penipisan yag terjadi pada persebaran $75 \%$

Dari Gambar 21 kita dapat melihat trend yang pada pengurungan ketebalan matrial bahwa merata pada semua ukuran partikel, dan penipisan yang paling tinggi yaitu penipisan sebesar $1.610^{-5} \mathrm{~m}$. Area yang memiliki ketebalan paling rendah menunjukkan tingkat keausan yang paling tinggi dan adanya potensi terbentuk initial crack pada area tersebut

Pada Kondisi persebaran partikel $100 \%$ kita dapat menyimpulkan data yang kita miliki

Tabel 5

Simulasi Pada Kondisi Persebaran 100\%

\begin{tabular}{ccc}
\hline \multirow{2}{*}{ Ukuran Partikel } & \multicolumn{2}{c}{ Keteblan } \\
\cline { 2 - 3 } $100 \mu \mathrm{m}$ & $2,25 \mathrm{E}-05$ & Minimum \\
\cline { 2 - 3 } $120 \mu \mathrm{m}$ & $2,25 \mathrm{E}-05$ & $6,76 \mathrm{E}-06$ \\
$150 \mu \mathrm{m}$ & $2,25 \mathrm{E}-05$ & $6,76 \mathrm{E}-06$ \\
\hline
\end{tabular}

Dari Tabel 5 kita dapat menghitung pengurangan ketebalan gritcone dan dirangkum dalam Gambar 22

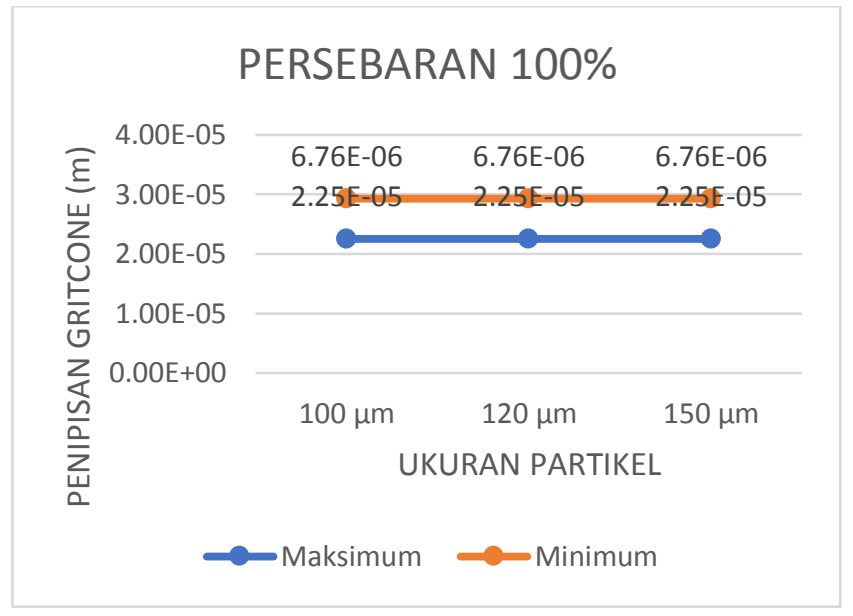

Gambar 22 Penipisan yag terjadi pada persebaran 100\%

Dari Gambar 22 kita dapat melihat trend yang pada pengurungan ketebalan matrial bahwa merata pada semua ukuran partikel, dan penipisan yang paling tinggi yaitu penipisan sebesar $6.7610^{-6}$. Area yang memiliki ketebalan paling rendah menunjukkan tingkat keausan yang paling tinggi dan adanya potensi terbentuk initial crack pada area tersebut ${ }^{[2]}$.

Dari hasil diatas seusai dengan jurnal ${ }^{[3]}$ yang menjelaskan Massa Jenis , kekeraan, sudut pantul, bentuk partikel itu lebih berpengaruh dalam menaikan tinggkat ke erosion dari suatu sistem ketimbang pada kenaikan massa. Sehingga didapatkan hasil yang hampir merata, dan menuurut . Dalam logam, pengaruh ukuran partikel abrasif minimal untuk ukuran partikel> $100 \mu \mathrm{m}^{[4]}$. Di bawah ukuran partikel ini, laju keausan berkurang dengan cepat dengan penurunan ukuran partikel.

\section{KESIMPULAN}

Dari Hasil simulasi yang telah dilakukan dapat disimpulkan bahwa pengaruh ukuran partikel tidak memberikan pengaruh terhadap kegagalan yang terjadi dan dari penilitian kali ini didapatkan data sebagai berikut

- Ketebalan gritcone minimum pada Persebaran $75 \%$ dan $100 \%$ adalah 0,00998403 $\mathrm{m}$ dan 0,00999324

- Ketebalan gritcone maksimum pada Persebaran $75 \%$ dan $100 \%$ adalah $0,00998715 \mathrm{~m}$ dan 0,0099775

\section{DAFTAR PUSTAKA}

[1] Chi, Ai dan Li Yuwei. 2013. The Model for Calculating Elastic Modulus and Poisson's Ratio of Coal Body. China : Northeast University

[2 ]Bayer, Raymond G., 2002, Fundamentals of Wear Failure, USA, HNB Pub

[3] Desale, Girish R. 2005 Effect Of Physical Properties Of Solid Particle On Erosion Wear Of Dctile Material. USA : Indian Institute of Technology

[4] Ratia, Vilma., 2015, Behavior of Martensitic Wear Resistant Steels in Abrasion and Impact Wear Testing Conditions, USA, Temepre University of Technology 